\title{
Expeditions among the Lutsi Estonians and the design of Language Learning Materials
}

\begin{abstract}
The Lutsi Estonians (Lutsis) are a historically South Estonian-speaking minority that has inhabited a network of more than 50 villages in the historical rural parishes of Pilda, Nirza, Brigi, and Merdzene surrounding the city of Ludza, in the Latgale region of eastern Latvia, for at least three to four centuries. Between 2013 and 2016, I received funding from the Kone Foundation to document the present state of the Lutsis and to write a Lutsi language primer for Latvian speakers. The first part of this paper gives an overview of previous work on Lutsi followed by a description of the present state of the population of Lutsi descendants as I found it during the period of my Kone-funded research. The second part of this paper describes the Lutsi language primer, beginner's grammar reference, and dictionary, which were the other main products of this research and discusses plans for their future use. The first extensive documentation of the Lutsis, their culture, and language was undertaken by researcher Oskar Kallas in 1893. Relatively substantial subsequent documentation of Lutsi was carried out over subsequent decades as the Lutsi population continued to be assimilated primarily into the Latvian speakers of their home region. The last fluent speaker died in 2006 and the last known passive partial speaker died in 2014. Presently, some fragmentary knowledge of Lutsi survives among descendants; however, the Lutsi Estonians today have shifted entirely to using Latvian, and less frequently also Russian, as their primary language.
\end{abstract}




\section{Introduction}

This paper describes some of the findings of my Kone-funded research during the period between 2013 and 2016 when I was funded to document the current state of the Lutsi Estonians, one of the three South Estonian language island communities and one of two that are located within present-day Latvia. The Lutsis were first documented extensively in 1893 by researcher Oskar Kallas ${ }^{1}$. During the course of the $20^{\text {th }}$ century, the Lutsis and their language would be subject to relatively extensive though infrequent documentation with many years and even decades separating major documentation efforts (see Section 5). In addition, this paper describes the other portion of my Kone-funded work, which is the design and writing of a Lutsi language primer intended to be used for reacquainting Lutsi descendants and other residents of Latvia with the Lutsi language, culture, and people as well as the beginner's grammar reference and dictionary, which were also products of this work. An additional product of my Kone-funded work not discussed in this paper, is an informative website about the Lutsis, the Lutsi language, and my research (located at: www.lutsimaa.lv), which is available in Latvian, English, and Estonian. This paper gives new facts, which I unearthed during the course of my work and also tells some of the stories I encountered during this same work, which are relevant to characterizing the present situation of the community of Lutsi descendants.

Section 2 of this paper discusses naming conventions used for the Lutsis in English, Latvian, and Lutsi; section 3 discusses the history of changing administrative boundaries in the Lutsi home region and how this relates to describing the location of different Lutsi communities; section 4 describes the fieldwork in the historical Lutsi region in eastern Latvia, which I undertook for this research; section 5 describes the linguistic background of the Lutsis and the history of Lutsi documentation; section 6 describes the present state of the Lutsi language; section 7 discusses the possibility of Estonian or Lutsi habitation in other villages beyond those visited by Kallas; section 8 discusses my Lutsi primer, its layout, and the orthography I use for it; section 9 provides a short overall summary of the subjects in this paper.

1. Kallas published a report of his work as the book Lutsi maarahvas in 1894. 


\section{On names}

The terms "Lutsi Estonians" and "Lutsis" are used interchangeably in this report. "Estonian" is also used to refer to this community unless otherwise indicated to be related to Estonia specifically. The reason for this is that the Lutsis themselves identify the ethnicity of their Lutsispeaking relations - or in some cases their own ethnicity - as Estonian. While perhaps one could ponder whether successful language revitalization would bring about the emergence of a unique Lutsi identity, such an identity has never really existed in the past. Therefore, I am cautious about claiming one here for the Lutsis.

One may wonder then why I do not simply always refer to the Lutsis consistently as Estonians throughout this paper. This is because, from the perspective of an exterior observer, the Lutsis clearly do form a unique community, which historically has spoken a unique variety of South Estonian and - especially presently - whose members, unlike Estonians in Estonia, see themselves as people connected with Latgale and with Latvia as a whole rather than with Estonia.

In conversation with various Lutsi descendants, I have not fully gauged the nature of their own view on their identity. In one very particular case, a Lutsi woman I interviewed did tell me that she considered herself to be Estonian rather than Latvian. However, during the course of this work I did not find other Lutsi descendants making such firm statements and self-identifying as Estonians.

In Latvian, the Lutsis are referred to as Ludzas igauni 'Ludza Estonians', igauni 'Estonians', or occasionally as luci 'Lutsis'. This final term luci or derived forms such as luciski 'in Lutsi' are somewhat rarely used, but do appear to a limited extent in some recent and forthcoming works such as the collection of translated Lutsi stories Ludzas igauņu pasakas ('Lutsi stories'; Godiňš 2015) and the volume on Lutsi history and origins Ludzas igauni: Zemes dieva tauta ('The Lutsis: People of the Earth God'; Korjus 2017).

In Lutsi, the Lutsis have referred to themselves as ēstläzeq 'Estonians' or mārahvas 'country folk'. Similarly, they have called their language $\bar{e} s t u k \bar{l} l$ 'Estonian language' or $m \bar{a} k \bar{l} l$ ' country language'. Presently, as mentioned above, the Latvian-speaking Lutsi descendants refer (in Latvian) to their ancestors as igauni 'Estonians' and to their ancestors' language as igaunu valoda 'Estonian language'. 


\section{Changing administrative boundaries}

The change in administrative divisions in Latvia from the pre-WWII years to the present creates a potentially confusing situation in discussing where the Lutsi villages are located. Prior to WWII and the Soviet occupation, Latvia had two types of administrative divisions. The top-level division aprinkis 'district' was composed of a lowerlevel division pagasts 'rural parish'. During the Soviet occupation, the administrative divisions of Latvia changed many times. The aprinkisis and pagasts divisions were eliminated at one point and ultimately replaced with a top-level division called rajons 'district'. The duties of the lower-level administrative division were in some sense shared between collective farms and the ciema padome 'village soviet' (also referred to just as ciems 'village') (Šksiņkis 1999: 69-72).

The boundaries of the administrative divisions of the Soviet period did not at all match those of the aprinkis or pagasts boundaries of the pre-WWII years. In 1990, with the end of the Soviet occupation, the rajons division remained, but the ciema padome/ciems division was renamed pagasts without any accompanying boundary changes (Šķiņķis 1999: 74). This meant that there were pre-WWII and postoccupation pagasts divisions with the same name, but totally different boundaries (e.g., Pilda pagasts, Nirza pagasts, Mērdzene pagasts, Brigi/Brigi pagasts). In speaking about the location of the Lutsi villages, this creates a real problem, because some of these villages are found in pagasts divisions of different names in pre-WWII Latvia as opposed to present-day Latvia.

More recently Latvia underwent a further administrative reform, culminating in 2009 with the elimination of both the rajons and pagasts division. These were replaced with a single type of administrative unit novads 'rural municipality'. The pagasts division still remains relevant, however, as it is used for the purposes of describing locations and still appears on published regional maps. To avoid confusion, in this paper all locations are given with respect to the location of the villages within their pre-WWII parishes. Maps 1 and 2 show a comparison between administrative divisions in the Ludza area before WWII (left) and currently (right). Cities of regional importance and other communities historically important to the Lutsis are shown on 
both maps. Map 2 also shows most of the villages visited by Kallas as well as the location of other villages (e.g., Špegi, Zurzi) mentioned elsewhere in this report.

\section{Fieldwork}

I conducted six trips to Ludza and the surrounding rural areas during the period of my Kone funding. Additionally, I traveled to the Ludza area one time prior to this funding in August 2012 when I first met the final person with passive knowledge of Lutsi, Antonina Nikonova, at her home in Pilda, Latvia.

The purpose of my fieldwork was to meet with and interview Lutsi descendants and document their knowledge of Lutsi language and culture as well as their own family history, in order to better understand the interrelationship between various Lutsi families. Through my existing contacts, most notably Professor Karl Pajusalu of the University of Tartu and Hannes Korjus, a researcher of Latvian Estonians, I first began by meeting and interviewing the Lutsi descendants of whom they were aware. In addition, my first research trip was conducted in conjunction with Indrek Jääts and Maido Selgmäe of the Estonian National Museum (Eesti Rahva Muuseum). Jääts and Selgmäe were in the process of making a documentary film about the Lutsis (Kadunud hõim: Lugu Lutsi maarahvast. Lost Tribe: A Story about the Lutsi Estonians, released in 2014) and so through them I also met with and interviewed a number of Lutsi descendants.

After this initial trip, my fieldwork would be composed of meetings with individual descendants in Ludza, other particular villages, or other cities in the greater Ludza area. During the course of my field research, I traveled to as many of the 53 villages noted by Oskar Kallas as having Estonian-speaking inhabitants as I could. In the end I visited 40 of these villages or sites where these villages had once stood, and in subsequent years I have visited the remainder of these villages and village sites. I spoke with village inhabitants and in this way also was able to determine the level at which knowledge of Lutsi origins still persists in the actual villages where the Lutsis had lived in Kallas' time. 


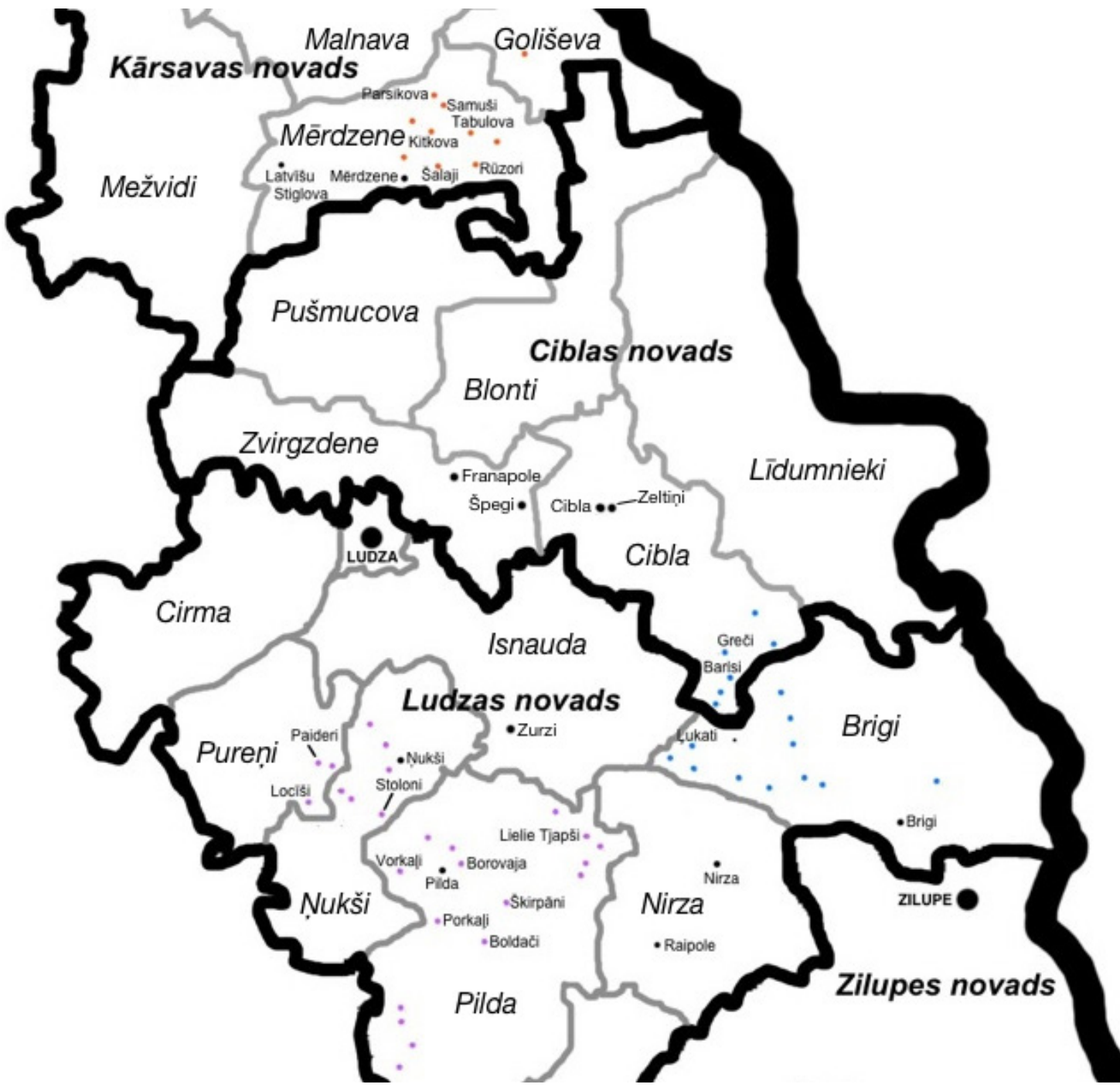

Maps 1 (left) \& 2 (above). Comparison between pre-WWII (left) and current administrative divisions (above) in the Lutsi region. (Top-level administrative division names shown in bold italics, lower-level pagasts division names shown in plain italics, towns significant to the Lutsis are shown on the map with/without names. Smaller dots on Map 2 mark Lutsi villages.) Maps by Uldis Balodis (utilizing information from Turlajs 2012: 46-47, 74-75 and RAPLM/PRD 2007). 
5. Background

The Lutsis are one of three groups of South Estonian speakers referred to collectively as the "South Estonian language islands". The Lutsis were located in villages spanning the pre-WWII rural parishes of Mērdzene (formerly, Mihalova), Pilda, Nirza, and Brigi (formerly, Janovole). The Leivus were a language island located in northeastern Latvia centered on the towns of Ilzene and Lejasciems near the city of Alūksne. A third language island, Kraasna, was located near the Lutsis but across the present-day border in Russia in a group of villages near the city of Krasnogorodsk. None of these South Estonian language varieties is spoken any longer (Kallas 1894, 1903; Niilus 1937; Korjus 2001; Pajusalu 2009). Map 3 shows the approximate location of the three language islands relative to present-day boundaries.

Documentation of the Lutsis occurred during four primary periods and one other more general period which followed. These include (1) Oskar Kallas' trip through the Lutsi region in 1893, (2) Heikki Ojansuu's written documentation in 1911 of the speech of inhabitants of Pilda rural parish and to a considerably lesser extent Nirza rural parish, (3) the written documentation of Lutsi during Latvia's interwar independence most notably by Paulopriit Voolaine and August Sang, and (4) the documentation of Lutsi by linguists from Estonia (Salme Nigol, Salme Tanning, Elna Adler, Aino Valmet) sometimes in conjunction with Voolaine, which occurred primarily in the 1960s and 1970s. The documentation from the 1960s and 1970s is also the main source of audio recordings of Lutsi. The fifth more general period of Lutsi documentation followed this documentation in the 1960s. Voolaine continued to travel to the Lutsi region and meeting with Lutsi families he knew until his death in 1985. Other researchers including Hannes Korjus and Karl Pajusalu have continued to document the present state of the Lutsi community primarily in the period following 2000. Most recently, my Kone-funded research has continued this tradition and has documented the current state of the Lutsi community as well as the last remnants of language knowledge which still exist presently among descendants of this community.

Each period of research documented knowledge which later periods of research either did not focus on or were unable to focus on 


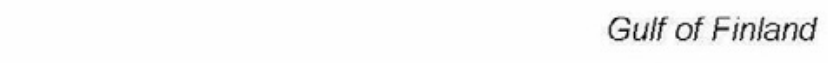


Likewise, Ojansuu's fieldwork in 1911 gives us examples of Lutsi spoken in villages in the Pilda rural parish for which later language documentation does not exist. Ojansuu wrote down word lists, stories, songs, and what appear to be transcriptions of other utterances spoken to him by his consultants. This information gives us the only record of speech from such villages as Raibakozi (Kirivä-kidze külä, in Lutsi) and Belamoiki (Belomoikino) in Pilda rural parish, for which no later records exist.

Documentation following Ojansuu focused on the villages of Lielie Tjapši (Sūre Tsäpsiq or Jāni külä, in Lutsi), Mazie Tjapši (Väiku Tsäpsiq), and Škirpāni (Kirbu külä) in Pilda rural parish and the villages of Greči (Grēki), Ščastl̦ivi (Tati külä), and Barisi (Mägize külä) in Nirza rural parish. The documentation from the third and fourth periods identified above would be the richest in terms of linguistic material. A large part of this documentation is composed of fairy tales or narratives focusing on experiences from the consultants' own lives. It provides an extensive record of Lutsi connected speech and, as stated above, work later in this period provides the only audio documentation of Lutsi. In addition, Voolaine and Sang wrote several unpublished pilot studies of subjects focusing on aspects of Lutsi phonology and morphology, which are freely available at the University of Tartu Archives of Estonian Dialects and Kindred Languages (Tartu Ülikooli eesti murrete ja sugulaskeelte arhiiv) at 〈http://www.murre.ut.ee/arhiiv $/\rangle^{2}$.

Speakers of Lutsi have steadily decreased in number since their first estimation by Oskar Kallas. Kallas estimated a population of approximately 800 Lutsi speakers in 1893. Early in the twentieth century, Heikki Ojansuu (1912) and Villem Grünthal (1912) gave an estimate of about 200 Lutsi speakers. Paulopriit Voolaine (1925) estimated approximately 120 Lutsi speakers and August Sang (1936) estimated approximately 30-40 Lutsi speakers. The last mostly fluent speaker of Lutsi, Nikolājs Nikonovs, died in 2006. His widow, Antonīna Nikonova, who died in 2014, could not hold a conversation in Lutsi, but did appear to have a great deal of passive knowledge and was able to remember short phrases and individual words. Currently, Lutsi descendants remember a few individual words, a greeting, or at

2. This archive is described elsewhere in this volume (see Lindström, Lippus \& Tuisk 2019). 


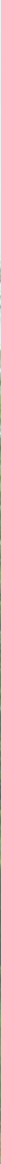

Figure 1. Antonīna Nikonova's and Nikolājs Nikonovs' house in Lielie Tjapši (left), likely the last place where Lutsi was spoken as a language of everyday communication. Photo: Uldis Balodis.

most a short phrase in Lutsi. At this time, there appear to be no remaining people with Lutsi speaking or comprehension abilities.

The origin of the Lutsis has long been a matter for discussion without clear agreement. The similarity of Lutsi to modern-day Seto argues against the Lutsis being a relic ancient population that would have lived in the Ludza area for more than a few centuries (Karl Pajusalu, p.c.). Two commonly stated theories regarding Lutsi origins are that the Lutsis either are (1) the descendants of South Estonian-speaking Catholic peasants who fled southern Estonia in the seventeenth century during the period of Swedish rule to avoid forced conversion 
to Lutheranism or (2) refugees fleeing southern Estonia in the eighteenth century as a result of the Great Northern War.

Lutsi last names are not necessarily of Estonian derivation. Some Lutsi last names, such as Mekšs and Germs/Germovs, may indeed derive from an Estonian source - in this case Mäks and Härm, respectively. Other last names, such as Jarošenko, Nikonovs, and Buls/Buḷ/s/ Bulis $^{3}$ do not seem to have an Estonian source.

\section{Current state of the Lutsi language}

As stated previously, the last known fluent speaker of Lutsi died in 2006 with the last knowledgeable passive speaker (the last speaker's widow) dying in 2014. Lutsi descendants do not appear to be concentrated in any particular area within the Ludza region. Many Lutsi descendants still live in Ludza, other larger towns in this region, or also in some of the villages documented by Kallas as having Estonian-speaking inhabitants (a list of these villages appears in Kallas 1894: 13-15). Just as other residents of Latvia, Lutsi descendants are to be found in the Latvian capital city of Rīga, other larger cities across Latvia, or abroad.

Among Lutsi descendants in their middle years, language loss occurred for the most part 2-3 generations ago. Thus, for these people their grandparents or even great-grandparents were the last generation who they remember speaking Lutsi. The main exception is the village of Lielie Tjapši where active use of Lutsi as an everyday language continued in the Nikonovs family until the $1980 \mathrm{~s}^{4}$. The Nikonovs family were, to my knowledge, the last family to maintain active use of Lutsi and I discuss this in further detail later in this section.

3. This last name has several variants.

4. I also recorded other accounts of language use during this same period. One of the Lutsi descendants I interviewed, originally from Lielie Tjapši but now living in a different village (Horoševa), recalled in the 1970s when he worked as a truck driver once having to drive a delivery to Tartu. This man does not speak Estonian and so decided that he would bring an old Estonian-speaking (i.e., Lutsi-speaking) man with him, so that he could communicate with local people in Estonian. However, when they arrived in Tartu, they quickly found that the Estonian (i.e., Lutsi) that this old man spoke was so different from the Estonian spoken by people in Tartu, that no one could understand him. 


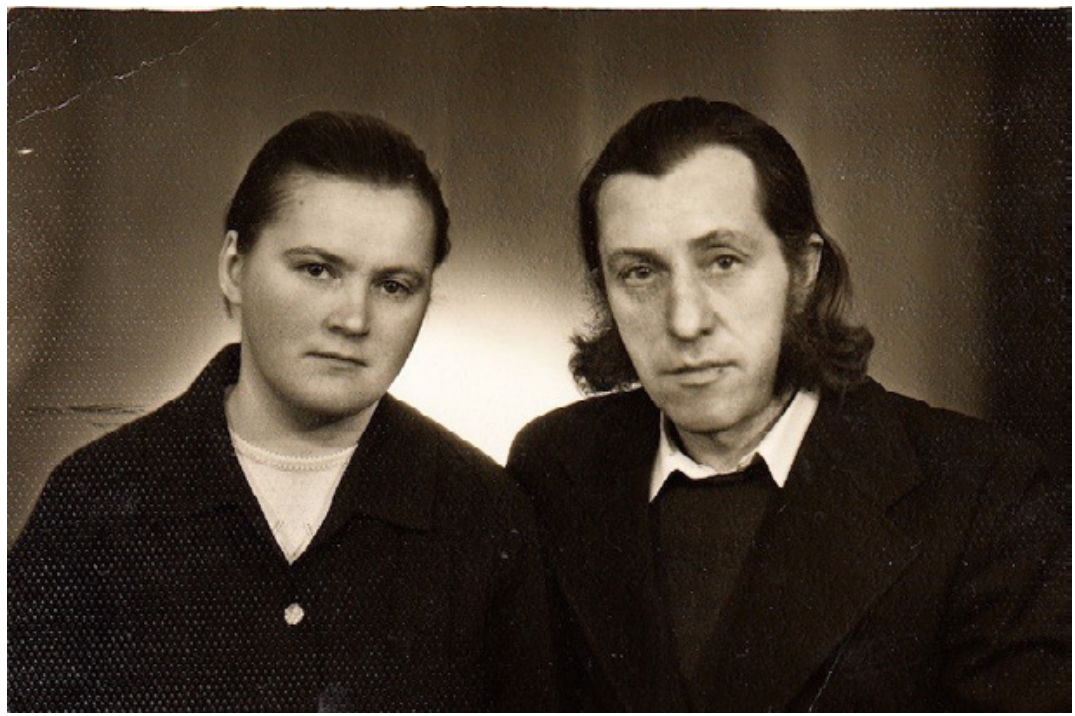

Figure 2. Antonina Nikonova and Nikolājs Nikonovs. Photo: Nikonovs family photo album.

Documentation of Lutsi before WWII suggests that active centers of use for Lutsi were the villages of Lielie Tjapši and Škirpāni in Pilda rural parish, the cluster of villages Greči, Ščasţ̦ivi, Barisi in Nirza rural parish, and Abricki (Dunduri, in Lutsi) in Brigi rural parish. However, as I state below, it is likely that several other villages, such as Vorkali (Vārkali) in Pilda rural parish, also still saw some dayto-day use of Lutsi in individual families, but for one reason or another the speech of these speakers was not documented during this time.

During the course of my Kone-funded research, Lutsi passed from having a proficient passive partial speaker to only having a few individuals with fairly sparse knowledge. The last known person within the group of Lutsi descendants to have had an actual degree of proficiency in Lutsi was Antonīna Nikonova née Strumpe (19492014). Mrs. Nikonova was the widow of Nikolājs Nikonovs (19442006) who was the last person reasonably fluent in the Lutsi language. Both Mr. and Mrs. Nikonovs were from Lielie Tjapši village in Pilda rural parish. They both were relatives of some of the more famous 


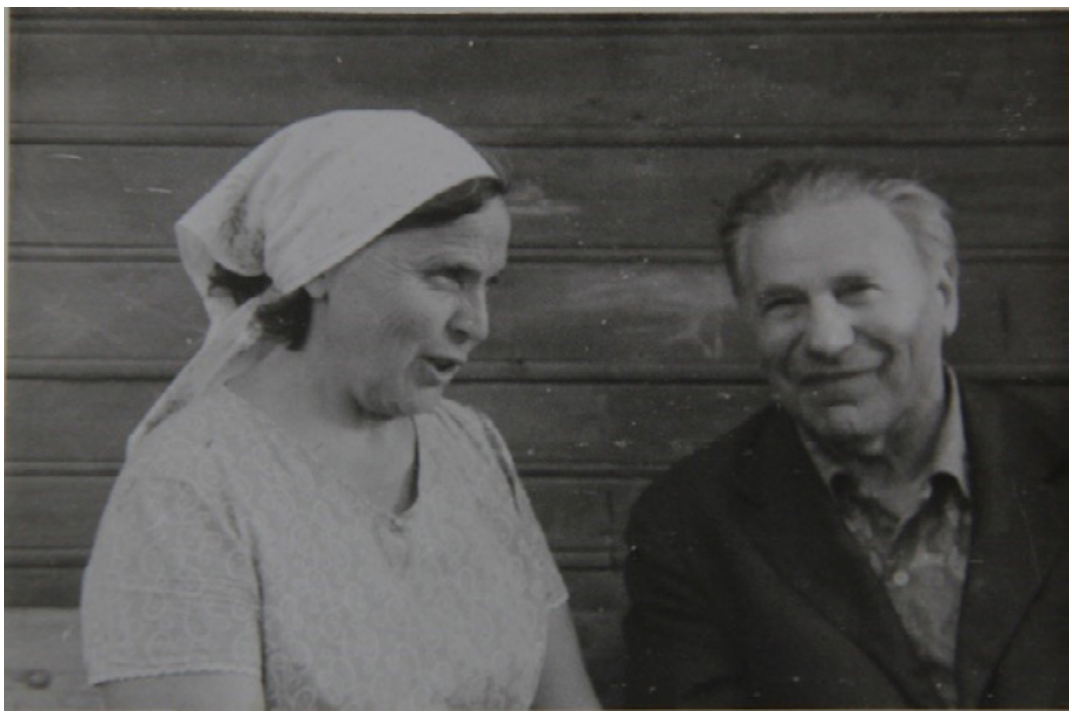

Figure 3. Antoṇina Nikonova (Nikolājs Nikonovs' grandmother) and Paulopriit Voolaine. Photo: Nikonovs family photo album.

Lutsi speakers that linguists had worked with in the $20^{\text {th }}$ century. Mr. Nikonovs' grandmother was Antonina Nikonova and his great-grandmother was Tekla Jarošenko. Mrs. Nikonova (Mr. Nikonovs' widow) was more distantly related to Tekla Jarošenko.

From stories told by Antonīna of her husband's grandmother Antonina, one gets the impression that Antonina Nikonova née Jarošenko (1898-1983) was a driving force behind the continued use of Lutsi in Lielie Tjapši. She would speak Lutsi to her grandson Nikolājs and she would encourage other Lutsi residents of Lielie Tjapši to speak Lutsi. Another story I was told in the course of one of my interviews was that Antonina would sometimes greet strangers who she would encounter in her home village by speaking Estonian (i.e., Lutsi) to them. Her death in 1983, also likely marked the end of active use of Lutsi.

I first met Antonina Nikonova in the late summer of 2012 and after the beginning of my Kone grant in April of 2013, met with her repeatedly over the course of the following year. I observed that 
in interacting with more proficient speakers of Estonian and South Estonian, she would understand individual phrases said to her. She also would volunteer individual words, such as the names of animals or short phrases, such as "I love you" told as part of a longer story in Latvian or Russian. I do not know of and have not found any other individuals who have the level of proficiency in Lutsi that Mrs. Nikonova still had, therefore with her passing it seems logical to conclude that there is most likely no one remaining who can understand Lutsi at the level that she could.

In the course of my field work trips revisiting the villages that Kallas noted as having Estonian-speaking inhabitants in 1893, I found that in some places there were still individuals who knew a few words of Lutsi. In Lukati (Lukodi, in Lutsi) village in Nirza rural parish there were two women, one who was older middle-aged, one who was elderly ${ }^{5}$, who both still remembered a greeting in Lutsi (i.e., tereq, tereq). In Ludza I met a very elderly woman in her 90s whose family was from Abricki village in Brigi rural parish. She, however, grew up in a non-Lutsi-speaking village, Voiti. She remembered a few Lutsi numerals, though after the numeral 'four' she mixed them with German. In Boldači (Paldatsi, in Lutsi) village in Pilda rural parish, I met a man in later middle years whose family was originally from Mazie Tjapši village and who also remembered the tereq, tereq greeting.

In my first year of Kone-funded research, I met an older Lutsi descendant, Helēna Kravale who since has passed away. Ms. Kravale's Lutsi relations come from her mother's side of the family. Her maternal grandparents' last name was Mekšs, which is one of the last names associated with the Lutsis. Her maternal grandfather had been a Lutsi speaker and would speak Lutsi with his sister. She recalled that her maternal grandmother, who was Latvian (i.e., Latgalian), had actually learned Lutsi, but that her maternal grandparents had spoken Latvian (i.e., Latgalian) to their children. Ms. Kravale is pictured in Figure 4 with her niece and fellow Lutsi descendant, Līga Kondrāte, of Ludza.

Ms. Kravale was born in Potorova village though the roots of her Lutsi family are in Vorkalsi village in Pilda rural parish. She knew

5. The elderly woman told me that her family came from Barisi, which, as stated elsewhere in this paper, was one of the villages characterized by active use of Lutsi before WWII. 


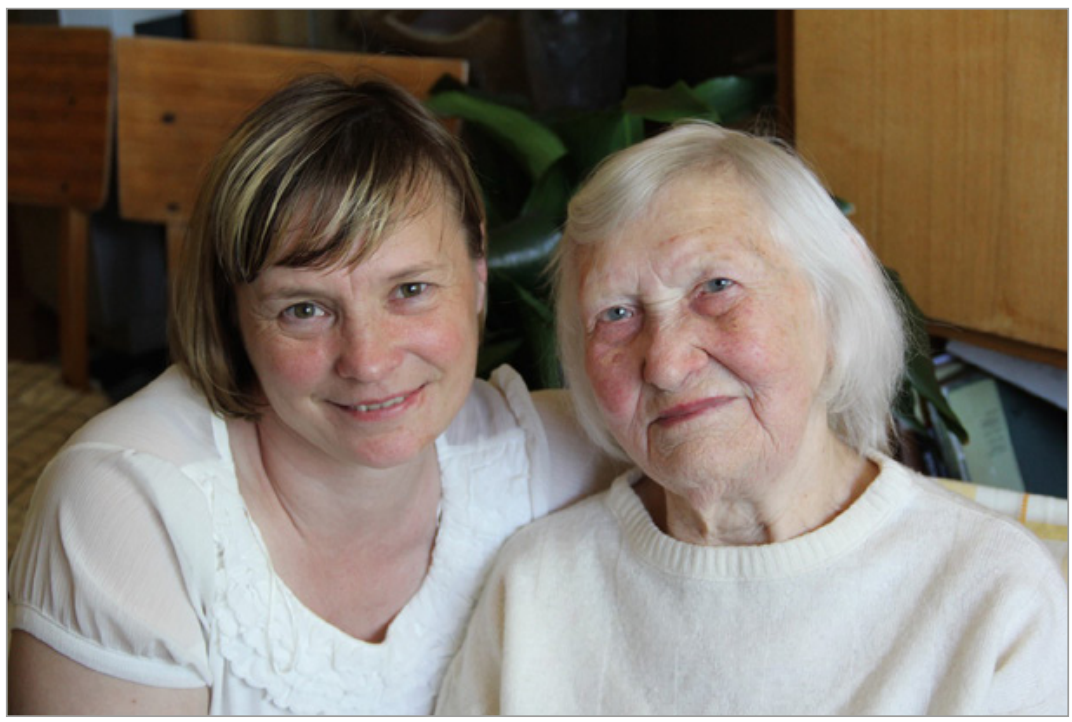

Figure 4. Lutsi descendants Līga Kondrāte (left) and Helēna Kravale (right). Photo: Uldis Balodis.

a single word of Lutsi, but the memory of this one word demonstrates the way in which some of the still existing fragmentary knowledge of Lutsi has survived among Lutsi descendants. The word Ms. Kravale remembered was suzi 'wolf'. She knew it because she remembered her mother telling a story of once walking home as a child and being followed by what seemed like a large dog. When she returned home she had told her parents about this dog and she remembered them speaking about it with each other excitedly in Estonian (i.e., Lutsi). Her father's use of the word suzi had stood out to her (as apparently the "dog" was in fact a wolf) and so for this reason this one word of Lutsi remained known in her family at least up to family members in their early middle years (40s) today.

The person with the most knowledge today is most likely a woman I met in Barisi village in Nirza rural parish. She could still count to ten in Lutsi and remembered a sentence in Lutsi that was the beginning of a fairy tale that her grandfather would tell. It seems entirely possible that there are more people beyond those that I found in the 
course of my work who possess this kind of memory of individual words or perhaps even short phrases. However, it seems unlikely that there are any unknown speakers of Lutsi remaining just based on the complete absence of anyone with even passive proficiency other than Mrs. Nikonova who passed away in 2014.

One other interesting observation to make is that Lutsi knowledge likely persisted in villages beyond those where Lutsi was documented in the $20^{\text {th }}$ century. The fact that individuals with whom I spoke had memories of grandparents with Lutsi knowledge in other villages (Sokāni, Vorkalii) and that I found people with some very basic knowledge in yet other villages (Lukati) suggests that prior to WWII there may well have been somewhat proficient speakers or at least people with some passive Lutsi knowledge living in these villages. We have very few data points with which to confirm this ${ }^{6}$. So we cannot know exactly how the retreat of Lutsi knowledge specifically proceeded in the Pilda and Nirza rural parishes.

Mērdzene Estonian was already fairly far gone by the time Kallas documented it in 1893. In visiting this region and its villages, I found little remembrance of Estonian heritage aside from a few specific individuals. One such individual is Ilmārs Silkāns (2011) who recalls in an article that he himself wrote that in his youth a local minister had talked about Estonian heritage in this area. In visiting the villages of Mērdzene, I found signs of Lutsi roots mainly in the presence of the last names such as Buls/Bul̦/Bulis noted by Kallas (1894: 33) as being among those characteristic of the Lutsis or Lipskis, which is similar to the last name Lipskina (masculine form: Lipskins) of one of Kallas' consultants in the Mērdzene rural parish (Kallas 1894: 75). However, there was no sign of any knowledge of Lutsi in the Mērdzene villages - not even on the level seen among some Lutsi descendants in Pilda and Nirza rural municipalities.

6. It should be noted that Ojansuu records Lutsi language data from Vorkaļi village as part of his 1911 documentation of the Lutsis and their language. So, at the very least it can be confirmed that Lutsi was still spoken there in the early twentieth century. 


\section{Other Estonians - possible other Lutsis}

In the course of this research, I have encountered intriguing signs that there may have been other Estonian speakers in the Ludza region beyond those living in the villages visited by Kallas. The uncertainty arises from not knowing the source of these people or anything about the language they spoke. Did they migrate at the same time as the rest of the known Lutsi population? Are they more recent arrivals from Estonia who quickly assimilated? Or are they the final remnants of even older migrations of Estonians predating the more well-known Lutsi community?

\subsection{Cibla}

I found one such possible group of Estonians following a lead from a relative of mine, Irēna Okuñeva ${ }^{7}$, who lived in the village of Felicianova. This has a personal connection for me, as part of my own family, through my paternal grandfather, comes from this region and his family name, Soikans, has been given in some lists (e.g., Latkovskis 1968: 94), as a name of Finno-Ugric origin. However, this has always been mysterious to me, as in my own family no memory of Estonian origins exists. Additionally, I have not been able to find evidence for an Estonian origin for "Soikans" beyond the possible Estonian etymologies given by Latkovskis in his monograph ${ }^{8}$. Therefore, one of the directions I pursued in these years was attempting to determine whether my own relatives from the Soikans family are indeed of Estonian descent. My relative in Felicianova is from a parallel family line (last name: Ulass). Our last common ancestor was in my great-great-grandparents' generation.

Mrs. Okuneva herself had no knowledge of Estonian ancestry in our shared family, but over time I noticed that the Ulass last name continued to appear in Lutsi contexts. (The exact same thing can be said for my own family's last name - Soikans.) For example, I found that a member of the Ulass family was married to a known Lutsi family from Greči village in the Nirza rural parish. By coincidence, while

7. Mrs. Okuneva was alive throughout the course of my Kone-funded research, but passed away in early 2017.

8. Latkovskis (1968: 94) gives soik 'silence, peace' and soikuma 'to become calm' as possible Estonian etymologies, but then also sojka 'jay' as a possible Russian etymology for Soikans. No further information is provided as to how these etymologies were arrived at or what background, aside from surface similarity, links them to "Soikans". 
eating lunch one day with the people working at the Ludza Handicrafts Center (Ludzas Amatnieku Centrs), one of the women there told me that her husband's family had Estonian ancestry and it happened to be that her husband's family name was Ulass. Speaking further with one of this woman's husband's relatives, it turned out that indeed she remembered that Estonian had been spoken by her Ulass grandparents.

Just as in the accounts of a number of Lutsi families from known Lutsi villages, these Ulass great-grandparents had used their Estonian as a "secret" language using it as a means to have private conversations in front of their children. Their home village had been Zeltini, which is directly next to Cibla. Interestingly, or perhaps not surprisingly, Zeltini is also the village that my own Ulass relative from Cibla identified as her family's ancestral village.

Thus, it appeared from these conversations, that there is evidence that there was at least one family of Estonian speakers living in Zeltini in the $20^{\text {th }}$ century. Yet, it is important to state that as interesting as this newfound information is, there is much that is unknown about this situation. Given the close proximity of Cibla to the other known Lutsi areas and the interaction of Ulass people with known Lutsi families, it seems possible that the Estonians of Zeltini were part of the same population as the Lutsis - just a portion unknown and not noticed by previous researchers. In speaking with this woman, she told me that her family also had links with Zurzi village in Pilda rural parish. While, Zurzi also has not been listed among the villages with Lutsi habitation, it is extremely close to other villages, such as Lielie Tjapši, with known Lutsi habitation. Thus, it is also possible that her family did not have an extended history in Zeltini village in Cibla, but instead were mainly from Zurzi.

What is at the same time puzzling and fascinating is that if indeed this woman's memory is correct and her grandparents were Estonian or South Estonian speakers, then in pre-WWII Cibla there were still at least a couple of speakers of this language completely unknown and unnoticed by researchers. Of course, one problem with this account is that we have no other corroborative evidence and only one person's account. Another problem is that the other side of this woman's family had the last name Matulis/Mutulis, which is known to have Lutsi connections in Brigi rural parish nearby. Thus, it could be that she was confusing which side of her family had Estonian (i.e., Lutsi) roots. Still, these possible connections are intriguing and worthy of further investigation. 
The story of my own family's connection is similar but even more tenuous. With the evidence of Estonian origin for the Ulass family and knowing that the Ulass and Soikans families stem from the same line (and at least in the case of the Soikans family, only one family is known to have this last name), it suggests that the Soikans family too could have some type of Estonian origins if the Estonian origins of the Ulass family are further corroborated.

\section{2. Špegi and Franapole}

In the Cibla area, but further to the west towards Ludza, there was another possible connection to Estonian speakers. An individual with the last name Buls who I interviewed in Rēzekne, discussed his family tree with me. In this family tree, he said that he believed one part of his family, with the last name Katkēvičs had Estonian speakers. He traced this part of his family to the village of Špegi. When I visited Špegi village, I spoke with people living there and they indicated that the Katkēvičs family no longer lived in the village, but had moved to a different village nearby called Franapole. I was not able to track down a further connection in Franapole, but in visiting the village cemetery I found a mix of known Lutsi last names such as Buls/Buls/Bulis with other names including Katkēvičs. Once again no clear proof that Lutsi or other Estonian speakers lived in this village, but somewhat suggestive of their presence there nevertheless. Further investigation of this Katkēvičs connection may yield additional information.

\subsection{Other areas}

Lutsis and people of Lutsi descent also surely lived in other villages in this region for reasons such as marrying into another non-Lutsi family. So, for example, the elderly Lutsi descendant I met in Ludza (discussed above in Section 6) who could still count to 4 in Lutsi, was born and grew up in a non-Lutsi village - Voiti - though her family came from a known Lutsi village in Brigi rural parish - Abricki. Similarly, today there are Lutsi descendants living in other villages in this region simply because they have come to own a home there, but not due to old family roots in these villages. 


\section{Lutsi Primer and Dictionary}

The design and writing of the Lutsi primer was the other major portion of my Kone-funded work during these last years. As discussed above, Lutsi no longer has an active speech community; however, there is still a relatively sizable group of descendants aware of their "Estonian" roots". Ultimately, I settled on creating a primer, which would teach readers some basics of Lutsi grammar, while also including sections describing the Lutsis, their history, the researchers who have studied them, historical and modern photographs of particular villages as well as samples of Lutsi from these villages given in the original and translated into Latvian. A primer containing language basics as well as specific information on communities in the Ludza region with which Lutsi descendants are familiar seemed to be the best way to reacquaint Lutsi descendants with their ancestral language and to raise interest in their ancestry.

In the future I plan to create a Lutsi language course, so that descendants and others interested in the Lutsi people will be able to learn some Lutsi at a rudimentary level. As a first step towards this future goal and as a supplement to the primer, I also created a beginner's grammar reference for Lutsi in the course of my Kone-funded work. I created this resource so that there would be an option for readers to take the next step and learn how the Lutsi language actually functions and is structured. The topics in the beginner's grammar reference will also serve as the basis for the language course I plan on writing in the future. Finally, during my last year of Kone-funded work, I created a learner's dictionary, which includes approximately 780 words translated into a number of languages. This is discussed in more detail below. The words in the dictionary were chosen based on the 100 most common words in Estonian and words, which typically are found in beginning language courses, as it seemed that words from these two groups would be the most useful to learners in beginning to construct simple sentences. The dictionary also includes conjugation tables for 71 verbs.

9. "Estonian" is how Lutsi descendants typically refer to their Lutsi origins. 
The target audience for the primer is first the Lutsi descendants themselves and second the larger Latvian-speaking public at large. The intended goal is at the minimum to acquaint descendants and others with the Lutsi language and the Lutsis as an ethnic group within Latvia; however, the hope is that the primer, beginner's grammar reference, and dictionary will lay the groundwork not only for a future language course, but also for eventual Lutsi language revival efforts.

\subsection{Orthography}

Lutsi has no consistent history of being used as a written language. Its only use as a written language seems to have been in the form of a few letters written in Lutsi by Paulopriit Voolaine and perhaps other Lutsi community members ${ }^{10}$ to Oskar Kallas, who at that time was serving as the ambassador of the Republic of Estonia to the United Kingdom. I found these letters in the archives of the Estonian Cultural Society. One such letter ${ }^{11}$ is reproduced in Figure 5.

Voolaine employed an orthography similar to that used for Estonian. Some additional sounds and features are marked in Voolaine's Lutsi orthography, which are not marked in the standard Estonian orthography. These include, palatalization, which Voolaine writes using a straight apostrophe $<^{\prime}>$ after the palatalized letter, and the glottal stop written using a curved apostrophe $<>>$. Long vowels and geminate consonants are written, as in Estonian, using a sequence of two identical letters. The close-mid back unrounded vowel in initial syllables is written, as in Estonian, with the character $<\tilde{0}>$. The retracted-e vowel (transcribed in the Finno-Ugric Phonetic Alphabet as $<\mathrm{e}>$ ) is also written with $<\tilde{\text { o }}>$, as in Võro. The vowels written in Estonian as $<\ddot{\mathrm{a}}>,<\ddot{\mathrm{o}}>,<\ddot{\mathrm{u}}>$ are written the same in Voolaine's Lutsi orthography.

10. The letters seem to be written in several different types of handwriting, so likely it was not only Paulopriit Voolaine writing them. However, it seems logical to presume that Voolaine was involved with encouraging and/or helping Lutsi community members to write these letters to Kallas in their own language.

11. The text of the letter translates as: "In Jānikülä (Lielie Tjapši), Sunday 28. I. 1934. Dear Mr. O. Kallas! A great thanks for the Bible, which we received today and started to read. There is much that gives knowledge (to us). The elder Lutsis:" (Thank you to Karl Pajusalu for this translation.) 


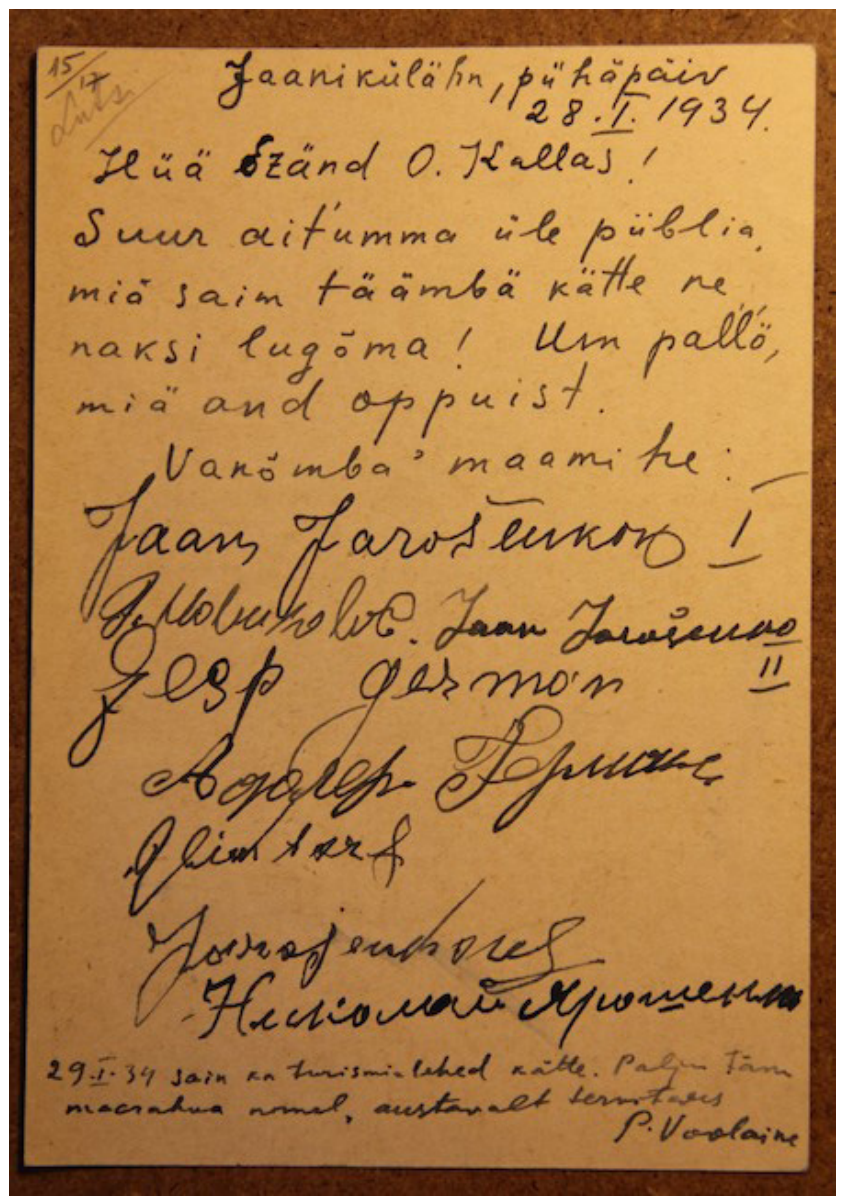

Figure 5. Letter written by Lielie Tjapši Lutsi residents and Paulopriit Voolaine to Oskar Kallas in 1934. Source: Estonian Literary Museum (Eesti Kirjandusmuuseum).

As my orthography would serve a different population than that using Voolaine's orthography, I chose not to adopt Voolaine's system for the Lutsi primer. The population that Voolaine studied was either still Lutsi-speaking or, if not, had fluent Lutsi speakers available for modeling speech. The current target population is Latvian-speaking and there are no Lutsi speakers available any longer for modeling proper pronunciation. Therefore, I decided to model my orthography on that used for Latvian and specifically for the High Latvian dialect 
(i.e., Latgalian), which has a separate literary tradition from the rest of Latvian and which is native to the region where Lutsi was spoken. In other words, Latgalian is the type of Latvian that most Lutsi speakers either speak themselves or would at least be familiar with. This is convenient, because while Latvian does not have a vowel equivalent to Estonian $<\tilde{\text { or }}>$, Latgalian does have a similar-sounding vowel. This vowel, written in Latgalian with $<\mathrm{y}>$ is a close central unrounded vowel. Much as in Lutsi, consonants in Latgalian are palatalized before front vowels with palatalization only being written explicitly for palatalized consonants occurring in other positions. In Latgalian, long vowels are marked with a macron, as in Latvian.

Thus, the Lutsi orthography I designed is a hybrid of the Latgalian orthography and the orthography used for Vorro. The intent was also to make an orthography that could be read as easily as possible by Latvian speakers and, while not necessarily resulting in a perfect rendition of Lutsi as once spoken by actual speakers, a reader's pronunciation would come fairly close to this. Again, the main issue at hand is the lack of Lutsi speakers and so readability and ease of use for non-speakers seeking to learn some Lutsi was the most important criterion I felt it was necessary to keep in mind.

In the Lutsi orthography I use in the primer, the close-mid back unrounded vowel in initial syllables is written with $<y>$, while retracted-e found in non-initial syllables is written with $<\mathrm{e}>$. As retractede sounds quite similar to $\langle\mathrm{e}\rangle$, this seemed a logical step to take to simplify the Lutsi orthography for readers of the primer and potential language learners. Palatalization is not marked before front vowels. Palatalization is written explicitly in other environments, and also preceding $<\mathrm{e}>$, using a comma under the palatalized letter as in Latvian and Latgalian. Long vowels are written with a macron, as in Latvian and Latgalian. Geminate consonants are written by doubling the consonant. The glottal stop is written, as in Voro, with $<\mathrm{q}>$. A comparison between Voolaine's orthography and mine is shown in Table 1.

In an earlier version of my orthography (described in Balodis 2015), I also marked half-long vowels with a macron. This is also done in the Livonian orthography and at the time I felt it would result in a more accurate Lutsi pronunciation. However, ultimately this seemed to yield a Lutsi spelling that seemed possibly too complicated 


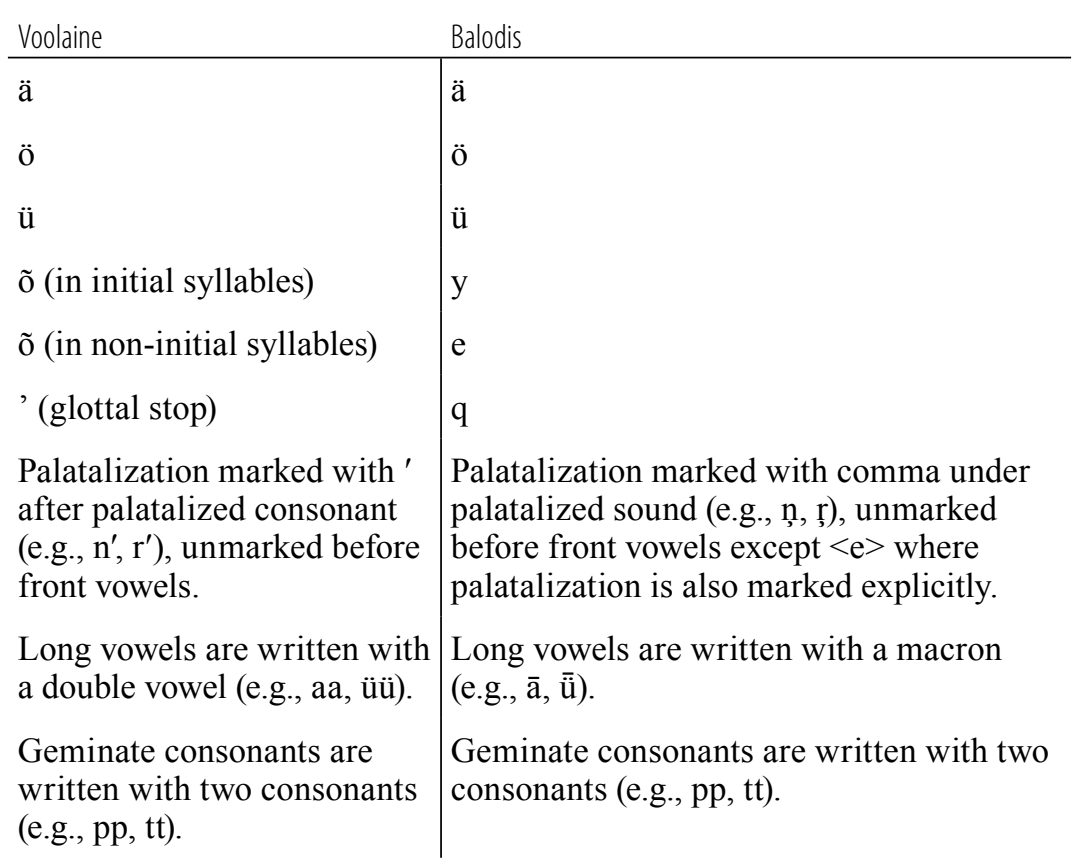

Table 1. Comparison of the Lutsi orthographies used by Voolaine and that designed by myself for the Lutsi primer.

to use for early stages of language revitalization. I may revisit the marking of half-long vowels in the future if language revitalization efforts begin to be successful.

The following compares the text of Voolaine's letter in his orthography and mine:

\section{Voolaine's orthography: My Lutsi orthography:}

Jaanikülähn, pühäpäiv 28. I. 1934. Jānikülähn, pühäpäiv 28. I. 1934. Hüä Ezänd O. Kallas! Hüä Ezänd O. Kallas!

Suur ait'umma üle piiblia, miä Sūr aițumma üle pīblia, miä saim saim täämbä kätte ne naksi lugõ- tämbä kätte ne naksi lugema! Um ma! Um pal'1'ö, miä and oppuist. pallö, miä and oppuist.

Vanõmba' maamihe:

Vanembaq māmihe: 


\subsection{Design of the primer and dictionary}

This section describes the design of the Lutsi primer, beginner's grammar reference, and dictionary. The Lutsi primer is divided into two main sections. The first section provides information on the Lutsi language and teaches the Lutsi alphabet and rudimentary grammar using example sentences. The second section gives information on particular Lutsi villages, their inhabitants, and also examples of Lutsi from each pagasts in order to show how Lutsi varied from region to region.

The first part of the primer begins with a description of the Lutsi orthography and other introductory material. The Lutsi alphabet then is presented with language examples structured in the following way. Two facing pages are devoted to each letter of the Lutsi alphabet. For each letter a word is selected which either begins with that letter or contains that letter, as not all sounds occur at the beginning of words. On the right facing page, the Lutsi word is given with its Latvian translation. Five sentence examples using this word are given below. As the nominative, genitive, and partitive cases are the three most important cases for forming simple expressions in Lutsi and as knowledge of a word's genitive case form is necessary for forming most other singular cases and the nominative plural, the first three examples for each word present the nominative, genitive, and partitive singular case forms in short sentence examples with Latvian translations. The other two sentence examples show a different case form in use, either a locative case or one of the other oblique cases such as the comitative.

On the left facing page, a photograph is presented, which is related to the word in the sentence examples. Primarily, I used either pre-WWII photographs showing Lutsi people in their villages or my own photographs of these communities from the last years. In the example shown in Figure 6, the word ahi 'oven' is presented with five examples below it and a picture of a Lutsi woman baking bread in an oven. The photograph is a historical photo of Lutsi speaker Tekla Jarošenko baking bread in her home in Lielie Tjapši taken by V. Niilus in 1936 and is from the archive of the Estonian National Museum (Eesti Rahva Muuseum). 
In the second half of the primer, I juxtapose historical and modern photographs of particular Lutsi villages, give information about those villages and their inhabitants, and also include text samples from the villages included in the primer from earlier documentation work. This was intended to show readers how Lutsi varied from region to region and village to village. Some of this material was quite old as, for example, the Lutsi spoken in the villages of Mērdzene pagasts is only known to us from the documentation of Oskar Kallas in 1893. When possible, each text example is presented as it would be written in the practical Lutsi orthography I developed in the course of this work. This is done so that readers who have learned how to use the Lutsi orthography can read each example out loud in order to hear approximately how it sounded and to make the Lutsi of each village more tangible to them. When available, the Lutsi is presented alongside its translation in literary Estonian and then my own translation of the literary Estonian into Latvian.

Figures 7-9 show examples from the second half of the primer. The villages discussed in this section are grouped according to the historical pre-WWII pagasts in which they are located. As described earlier in this report, while the pagasts administrative division existed both before and after the Soviet occupation of Latvia, the actual boundaries of these units were completely different in these two periods. To my knowledge, there exist no maps overlaying these boundaries on top of each other. As all Lutsi documentation and its related discussion is referenced using the old pre-occupation pagasts divisions, I continued this practice in my primer. However, so that present-day readers more acquainted with the modern-day pagasts divisions could understand where these villages are located, I drew maps, which show where present-day pagasts division boundaries fall within the boundaries of the historical pagasts divisions of Pilda, Nirza, and Mērdzene. The maps also show the location of each village discussed in that section. Figure 7 shows the map I created for the historical Pilda pagasts at the beginning of that section.

The example pages from this part of the primer are shown for Lielie Tjapši village. Figure 8 shows the introductory information on the village with historical pictures from the Estonian National Museum archive on the right. Figure 9 shows present-day photographs 


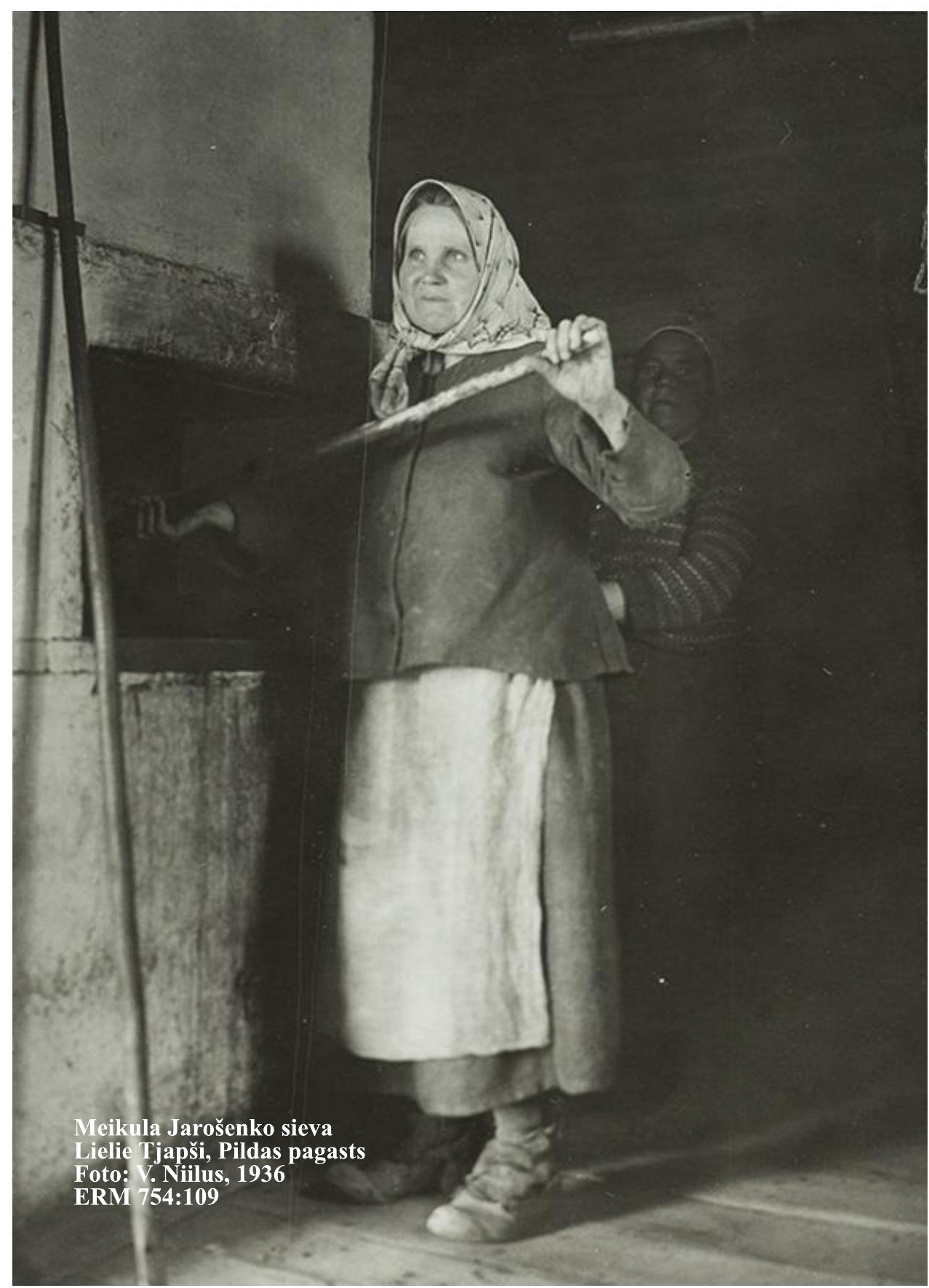

466 


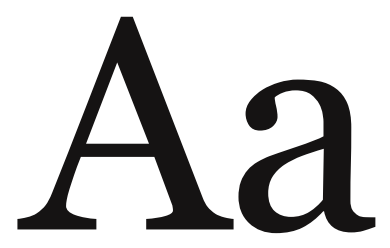

\section{ahi 'krāsns'}

\section{Ahi um pallav. \\ Krāsns ir karsta.}

Vanaimä saiz aho man.

Vecmāmiņa stāv pie krāsns.

Vanaimä näge ahja.

Vecmāmiņa redz krāsni.

Vanaimäl um ahi.

Vecmāmiņai ir krāsns.

Lēbä um ahohn.

Maize ir krāsnī.

Figure 6. Example pages from the language section of the Lutsi primer. 


\section{Pildas pagasts}

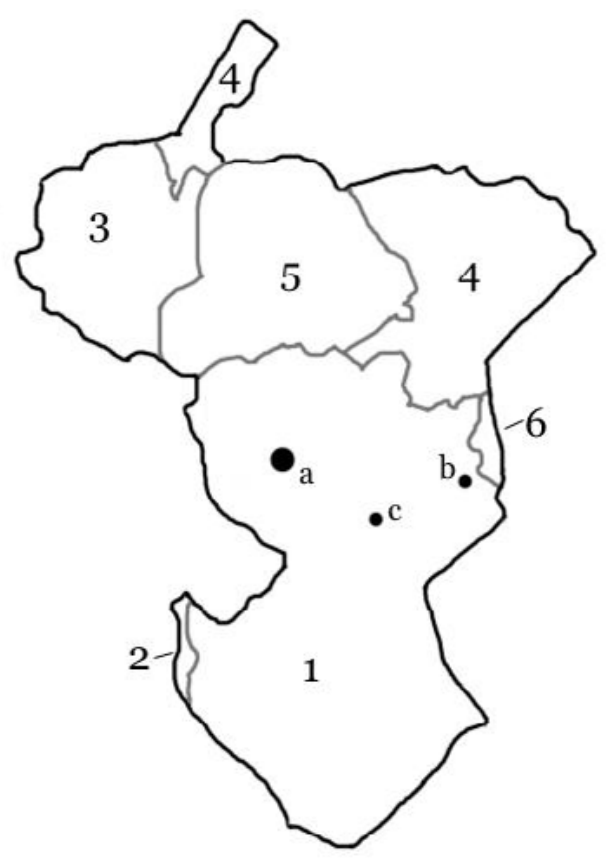

\section{Mūsdienu pagasti}

1 - Pildas pagasts

2 - Kaunatas pagasts

3 - Pureņu pagasts

4 - Isnaudas pagasts

5 - N̦ukšu pagasts

6 - Nirzas pagasts

\section{Ciemi}
a - Pylda (Pilda)
b - Sūre Tsäpsiq / Jānikülä (LIelie Tjapši)
c - Kirbu külä (Škirpāni)

Mūsdienu pagastu robežas rādītas pelēkā krāsā vēsturiskā pirmskara Pildas pagasta robežās.

Figure 7. Map of the historical Pilda pagasts with present-day (mūsdienu pagasti, in Latvian) boundaries shown with the location of villages (ciemi) discussed in this section. Lutsi village names are followed by Latvian in parentheses. 
of the village taken by me during the course of my fieldwork and then a description of the Nikonovs family on the right. As detailed earlier in this report, the Nikonovs family was the last family to actively speak Lutsi. The published version of the grammar will also contain Lutsi language examples with translations into Latvian from sources like the Eesti murded volume on the Estonian language islands (Mets et al. 2014).

As stated previously, in addition to writing the primer, I also wrote a beginner's grammar reference for Lutsi, which is intended as a supplementary resource for readers who wish to learn more about Lutsi grammar and who are interested in attempting to form more complex sentences. This is a "beginner's" reference in the sense that a full reference grammar would be more extensive, include more examples, and would show in detail the differences in Lutsi between villages. This grammar reference gives basic information with short explanations and sentence examples for a wide variety of topics, but is not as in-depth or as detailed as a full reference grammar would be and does not discuss Lutsi dialect differences. The grammar reference was created primarily based on my analysis of the Lutsi texts in Eesti murded IX (Mets et al. 2014). See Table 2 on page 474.

The Lutsi dictionary, which I created in the final year of my Konefunded work, is structured as a word list and contains approximately 780 words. As the dictionary is a word list, it was possible to translate each word into several languages, thereby increasing the scope of the potential audience for the dictionary. The languages (or written traditions, in the case of Latgalian) used for the translations include Latvian, Latgalian, English, Estonian, German and Livonian. Latvian and Latgalian were included as these are the languages or written forms, which now constitute the primary language of Lutsi descendants. English and German were included to give this work a point of connection beyond Latvia and allowing others to also learn about Lutsi. Estonian was included as it is a close relative of Lutsi and also due to the fact that Estonia is the historical point of origin for the Lutsis. Livonian was included as it and Lutsi are Finnic languages spoken in Latvia, its inclusion in the dictionary allows readers to compare these two languages and implicitly draws a connection between these two nations, which form part of Latvia's Finnic heritage. 


\section{Sūre Tsäpsiq / Jānikülä}

\section{Lielie Tjapši}

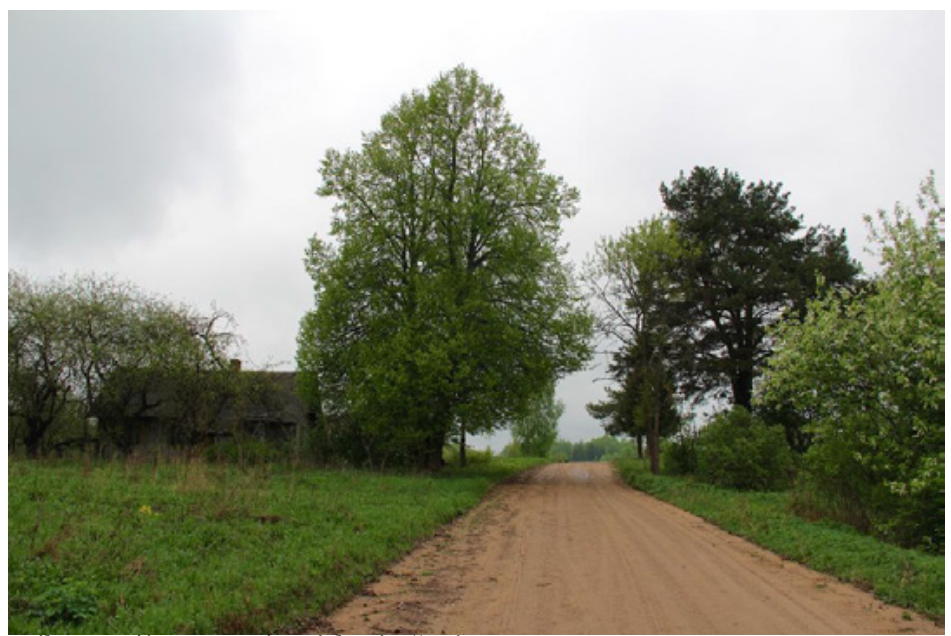

Nikonovu gimenes mājas Lielo Tjapsu ciemā.

Foto: U. Balodis, 2013

Lielo Tjapšu ciems ir pēdējā vieta, kur ikdienā vēl varēja dzirdēt sarunas Ludzas igauṇu valodā. Ludzas igauṇu valodas pēdējais runātājs, Nikolajs Nikonovs, nomira 2006. gadā, taču aktīvas sarunas Ludzas igauṇu valodā Tjapšu ciemā būtu bijis vēl iespējams šad tad dzirdēt līdz 1980. gadu vidum. Nikolaja vecmāmin̦a Anton̦ina Nikonova bija l̦oti prasmīga un dedzīga Ludzas igauṇu valodas runātāja līdz savam mūža galam 1983. gadā.

Pats nekad nesatiku Antoṇinu un arī ne Nikolaju, taču satiku Nikolaja atraitni Antonīnu Nikonovu, kas nemācēja brīvi runāt Ludzas igauṇu valodā, bet gan varēja daudz vārdu un īsus teikumiṇus pateikt. Man prātā vienmēr paliks no mūsu sarunām, kā viṇa teica - stāstot par savu vectēvu - Ludzas igauṇu valodā "maq sinnu sali” jeb "es tevi mīlu”. Šos vārdus viňš viṇai bija teicis un vēlāk skatoties Heikki Ojansū piezīmes pierakstìtas 1911. gadā redzēju šo pašu teikumu Ludzas igauṇu valodā. No valodnieciskās transkripcijas bija skaidrs, ka Antonīnas izruna - par spīti tam, ka viṇa brīvi nevarēja sarunāties Ludzas igauṇu valodā - bija ḷoti pareiza.

Citu stāsti arī liecināja par Ludzas igauņu valodas aktīvo lietošanu Lielajos Tjapšos vēl samērā nesen. Jānis Germans tagad Lielajos Tjapšos vairs nedzīvo, bet ir cēlies no šĩ ciema. Viṇš strādājis par šoferi un atceras, ka viens viṇa draugs - arī šoferis - 1970. gados vedis kravu uz Tartu Igaunijā. Igauniski neesot pratis un tāpēc esot paṇēmis līdzi no Lielajiem Tjapšiem vecu vīru, kas runājis Ludzas igauṇu valodā. Šoferis neesot zinājis, cik atškirīgas igauṇu valoda runāta Ludzas apkārtnē un tā, ko runā Igaunijā, patiesībā ir. Kad abi aizbraukuši uz Tartu, vecais vīrs ir centies sarunāties ar vietējiem cilvēkiem Ludzas igauṇu valodā, bet neviens neesot viṇu varējis saprast. Šis stāsts liecina ne tikai par to, ka 1970. gados bija vēl valodas pratēji Lielajos Tjapšos, bet arī to, cik atšḳirīga ir Ludzas igauṇu valoda no literārās igauṇu valodas. 


\section{Lielie (un Mazie) Tjapši toreiz}

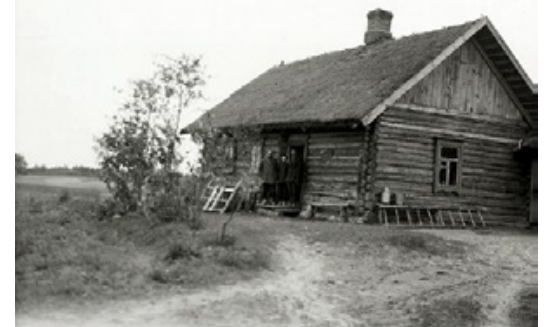

Meikula Jarošenko mājas

Lielie Tjapši, Pildas pag.,

Foto: V. Niilus, 1936, ERM 754:106
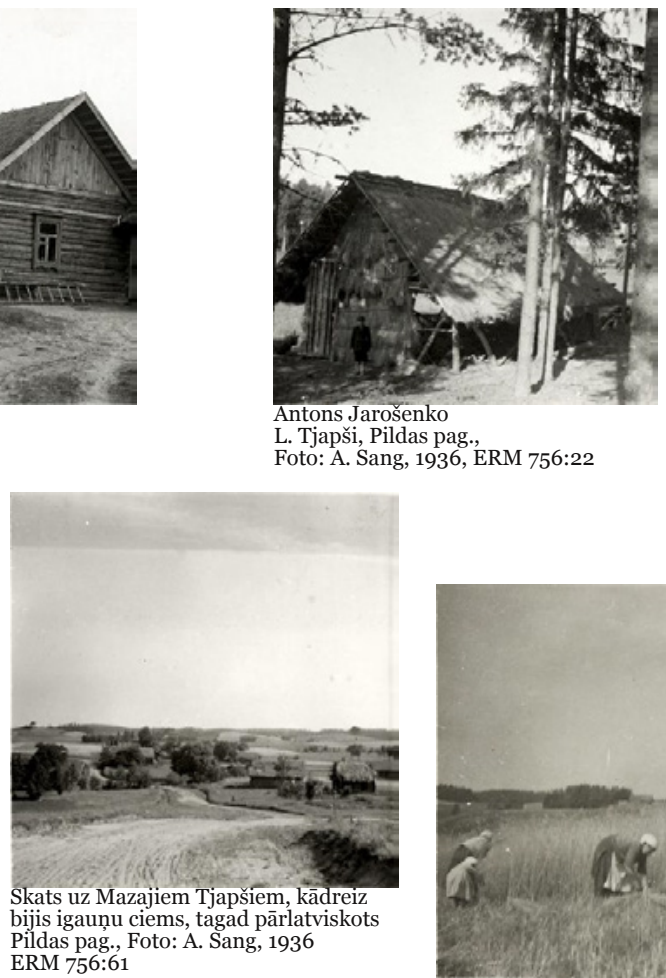

ERM 756:61

vecā tipa krāsns

Mazie Tjapši?, Pildas pag.,

Foto: A. Sang, 1936, ERM 756:53

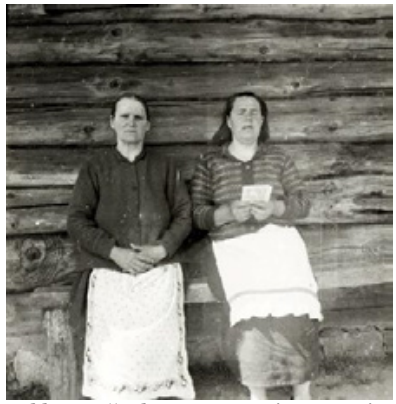

Tekla Jarošenko ar savu meitu Antoṇinu L. Tjapši, Pildas pag.,

Foto: A. Sang, 1936, ERM 756:13

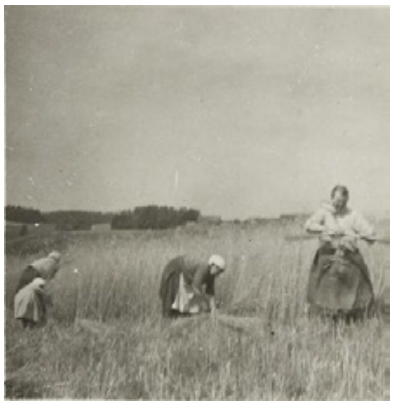

Rudzu plauja. u

L. Tjapši, Pildas pag.,

Foto: A. Sang, 1936, ERM 756:83

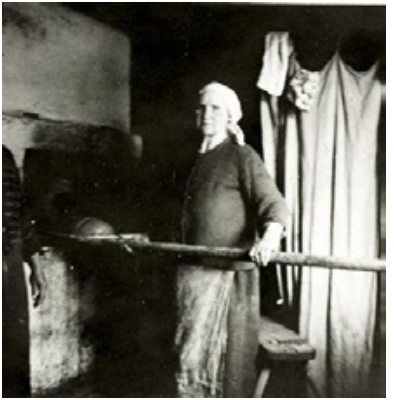

Maizes cepšana Meikula Jarošenko mājās L. Tjapši, Pildas pag., Foto: A. Sang, 1936 ERM 756:19

Figure 8. Introduction to the section on Lielie Tjapši village with historical images of this Lutsi village and its inhabitants. 


\section{Lielie Tjapši tagad}

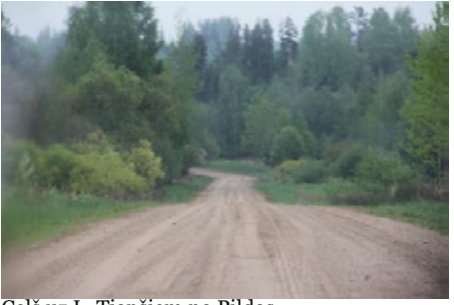

Cẹ̦š uz L. Tjapšiem no Pildas

Foto: U. Balodis, 2013

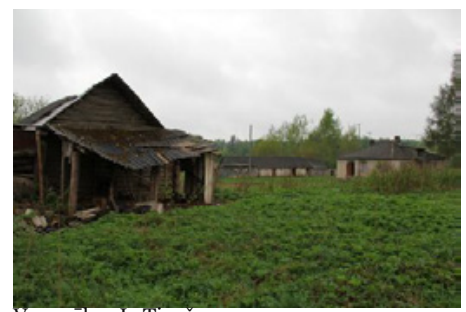

Vecas ékas L. Tjapsos

Foto: U. Balodis, 2013

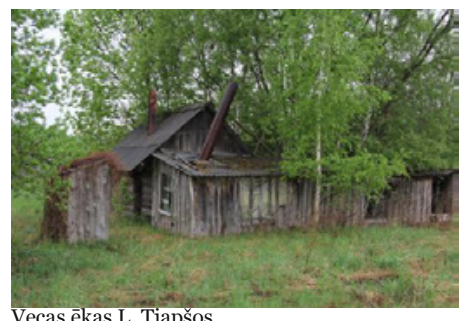

Foto: U. Balodis, 2013

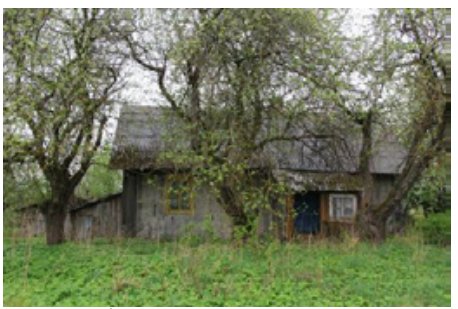

Nikonovu ğimenes mājas Foto: U. Balodis, 2013

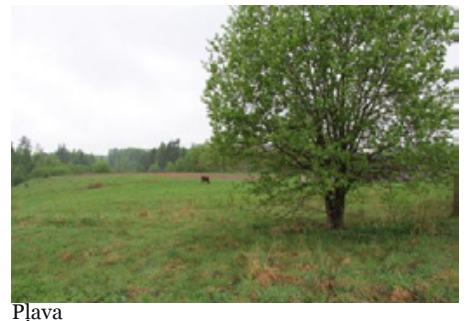

Foto: U. Balodis, 2013

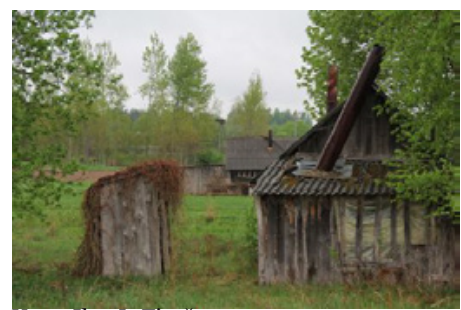

Vecas èkas L. Tjapšos

Foto: U. Balodis, 2013

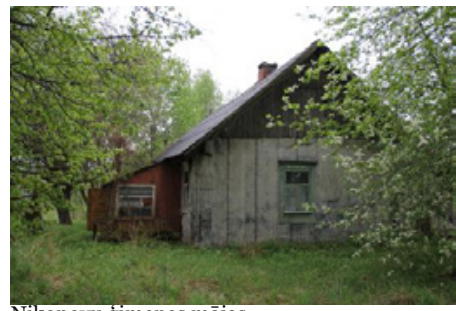

Nikonovu gimenes majas

Foto: U. Balodis, 2013

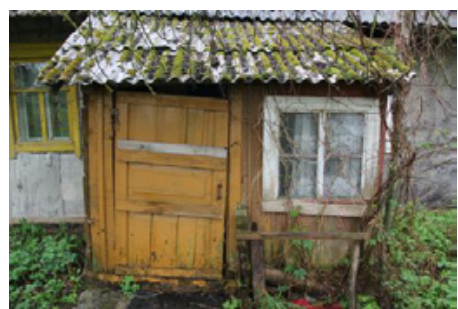

Nikonovu ǵimenes mājas

Foto: U. Balodis, 2013 


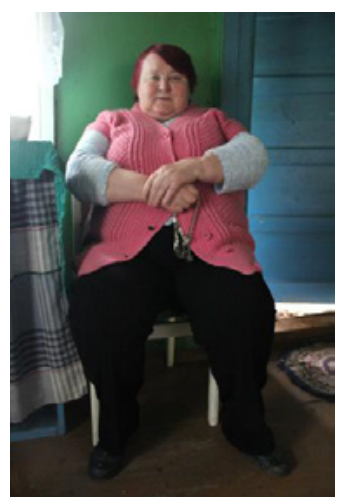

Antonīna Nikonova (1949-2014) gimenes mājās Lielajos Tjapšos. Antonina saprata un mācēja pateikt daudz vārdu Ludzas igauṇu valodā. Foto: U. Balodis, 2013

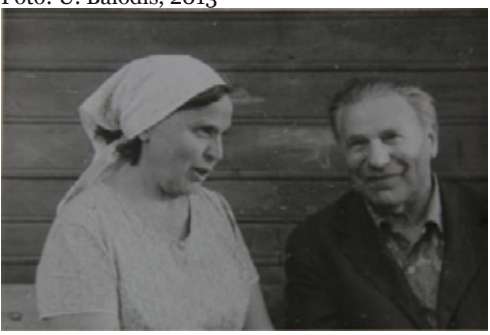

Antonina Nikonova (1898-1983) ar Pauloprītu Volaini Foto: Nikonovu ğimenes foto albums

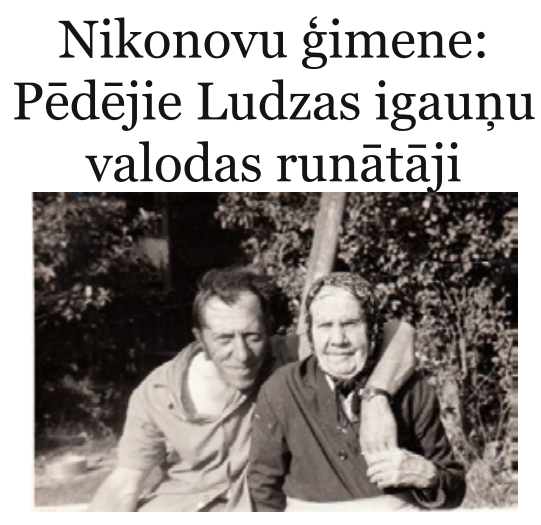

Pēdējie Ludzas igauṇu valodas runātāji: Nikolajs Nikonovs ar savu vecmāmiṇu Antoṇinu Nikonovu. Foto: Nikonovu ǵimenes foto albums

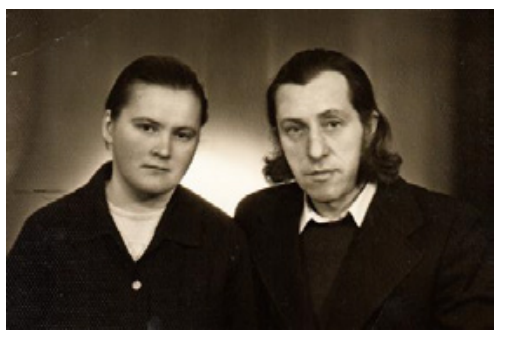

Antonīna Nikonova ar vīru Nikolaju Nikonovu (1944-2006) Foto: Nikonovu ǵimenes foto albums

1972. gadā, Guna Pence satikās ar Antoṇinu Nikonovu un pierakstīja vairākas interesantas viṇas atmiņas. Antoṇina bija visu mūžu dzīvojusi Tjapšos. Viṇas dēls prata ne tikai Ludzas igauṇu valodu, bet arī literāro igauṇu valodu, jo bija mācījies Igaunijā. Pence rakstīja, ka Antoṇinas mājas bijusi kādreiz kā "pulcēšanās centrs" Ludzas igauṇiem: "te svinēti svētki, notikušas sastapšanās ar pētniekiem no Igaunijas.” Pence arī rakstīja, ka Antoṇina bijusi vienīgā, kas vairs nodevusi Ludzas igauṇu valodu tālākām paaudzēm (Pence 1972:7-8).

Līdzīgi kā citu atmiṇās no pārējiem ciemiem, kas apskatīti šajā ābecē, Antoṇina atcerējās, ka agrāk igauṇi precējušies tikai viens ar otru. Viṇa gan nezināja kāpēc Ludzas igauṇi nonākuši Ludzas apkaimē kaut gan teica, ka "Tjapšos ienākušas 4 igauṇu ğimenes (un sākušas te dzīvot) no Germu [ciema] puses. Agrāk te [Tjapšos] bijis mežs. (Pence 1972:12).

Pauloprītam Volainem turpinājās draudzība ar Nikonovu ǵimeni līdz mūža galam. Par šo liecina fotogrāfijas Nikonovu ǵimenes albumos (dažas no kurām ir redzamas šajā lappusē). Pence arī pierakstīja Antoṇinas atmiņas par Volaines braucieniem, kas atbilst tam, ko arī pats dzirdēju vēl pat šodien no vecāka gada gājuma Ludzas igauṇu pēctečiem. Antoṇina atcerējās, kā Volaine bija dzīvojis pie viņas vairākas vasaras, bet arī bija palicis pie citiem Ludzas igauņiem.

Ziemassvētkos viṇš dāvanas bija vedis no igauṇiem Igaunijā. Pence raksta, ka svinības arī rīkotas pie Antoņinas un, ka "[r]īkoti lieli svētki, kur katram mazajam vajadzējis zināt kaut ko igauniski noskaitīt, tad arī dotas dāvanas.” (Pence 1972:12)

Figure 9. Lielie Tjapši in the present day and information on the Lutsi-speaking Nikonovs family. 


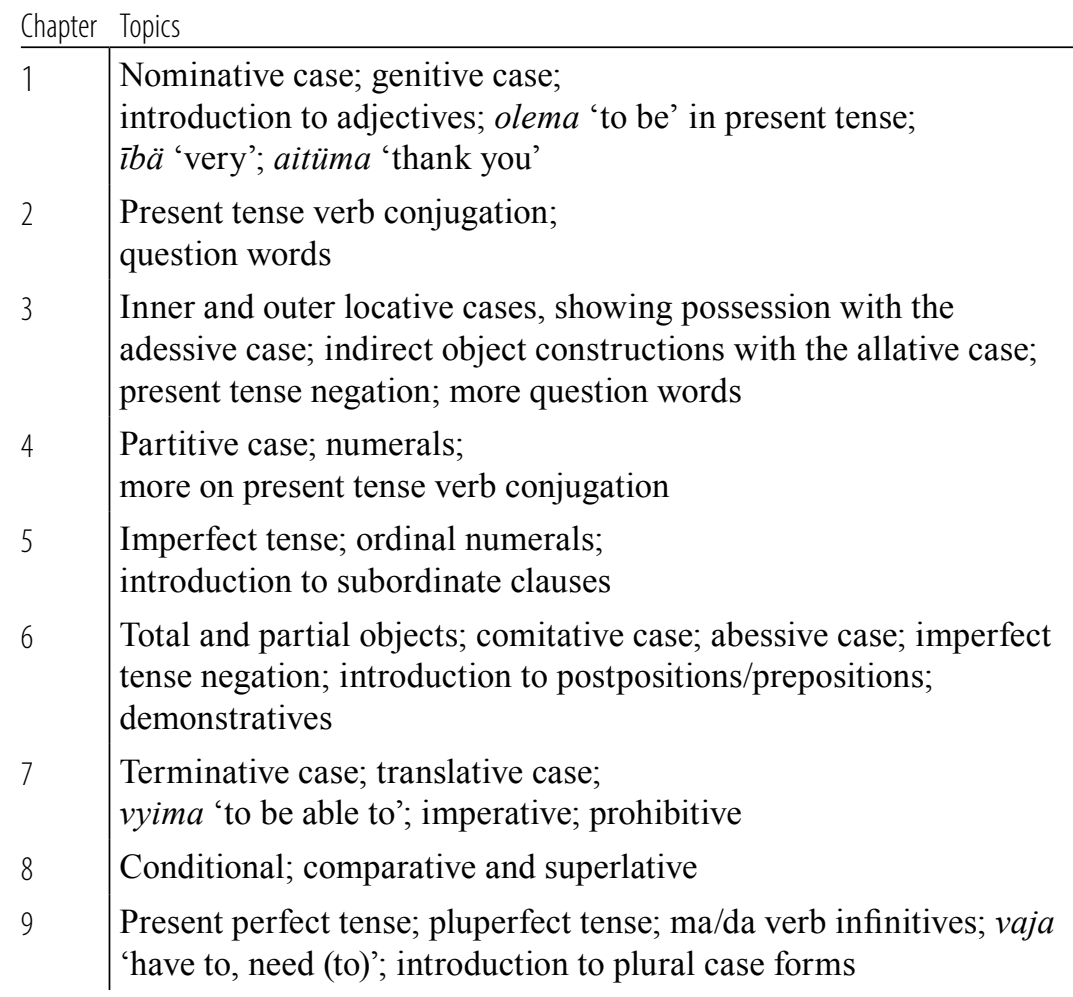

Table 2. Lutsi beginner's grammar reference chapter topics.

The back of the dictionary contains conjugation tables for 71 verbs found in the dictionary. These tables contain the affirmative and negative present, imperfect, conditional, and imperative forms as well as the $m a$ and $d a$ infinitive and $n u q$ participle forms. While Lutsi conjugation (and declension) types are no doubt similar to those of other South Estonian varieties, since these have not yet been fully described, I included the conjugation tables so that readers and students could use them as a reference in forming their own sentences utilizing the verbs in the dictionary. 


\subsection{Future and implementation}

With the completion of the Lutsi primer and following further editing and review, I am seeking a publisher for it. I may also make it freely available on my Lutsi website (www.lutsimaa.lv). I hope also to translate the Lutsi primer into English in the near future in order to make the information within it available to as wide of an audience as possible. Ultimately, I would like to use it for language classes, but further funding and planning will be required to realize this plan.

\section{Conclusion}

This paper describes some of my primary observations and accompanying stories characterizing the present state of the community of Lutsi descendants in eastern Latvia (i.e., Latgale), the background of research into the Lutsis as well as gives information about the language/culture primer, beginner's grammar reference, and dictionary I have written and the practical Lutsi orthography I have designed during the course of my Kone-funded research into the Lutsis in the period of 2013 to 2016. During this work I found that presently the Lutsi language is no longer actively spoken; however, I also found that Lutsi descendants are frequently aware of their heritage and so this may create fertile ground for attempting a language revitalization effort for Lutsi in the future.

\section{Acknowledgements}

I would like to give my sincerest and most heartfelt thanks to the Kone Foundation for making possible the work described in this report and for funding my postdoctoral research on the Lutsis between 2013 and 2016. I would also like to warmly thank Karl Pajusalu, Riho Grünthal, Hannes Korjus, Līga Kondrāte, Aija Andersone, Antonīna Nikonova, Indrek Jääts, Maido Selgmäe, and the many members of the community of Lutsi descendants with which I met and worked during the course of this research as well as the many others whom I spoke with and who supported my work during these years. 
References

Balodis, Uldis 2014: Lutsimaa: Land of the Ludza Estonians. Available at: 〈http://www.lutsimaa.lv/〉

- 2015: Writing down Lutsi: Creating an orthography for a South Estonian variety of Latgale. - Valoda: Nozìme un forma 6. Valodas sistèma un lietojums. Rīga: LU Akadēmiskais apgāds. 55-67.

Godiņš, Guntars 2015: Ludzas igauņu pasakas [Lutsi stories]. Rīga: Apgāds Mansards.

Grünthal, Villem 1912: Eesti asundused lätlaste seas [Estonian settlements among the Latvians]. - Eesti Kirjandus: 369-373.

Iva, Sulev \& Karl Pajusalu 2004: The Võro Language: Historical Development and Present Situation. - Language Policy and Sociolinguistics I: "Regional Languages in the New Europe". (International Scientific Conference. Rēzekne Augstskola, Latvija; 20-23 May 2004.) Rēzekne: Rēzekne Augstskolas Izdevniecība. 58-63.

Jääts, Indrek \& Maido Selgmäe 2014: Kadunud hõim: Lugu Lutsi maarahvast. Lost Tribe: A Story about the Lutsi Estonians. [Documentary film.] Eesti Rahva Muuseum.

Kallas, Oskar 1894: Lutsi maarahvas [Lutsi country folk]. Helsinki: Suomalaisen Kirjallisuuden Seura.

1903: Kraasna maarahvas [Kraasna country folk]. Helsinki: Suomalaisen Kirjallisuuden Seura.

Korjus, Hannes 2001: Ludzas rajona igauñi 2001. gadā [The Estonians of Ludza District in 2001]. Latviešu folkloras krātuves arhīvs, LKF Nr. 2116. 6. tabula.

2017: Ludzas igauni: Zemes dieva tauta [The Lutsis: People of the Earth God]. Rīga: Lauku Avīze.

Latkovskis, Leonards 1968: Latgaļu uzvōrdi, palames un dzymtas [Latgalian last names, nicknames, and families/clans]. München: Latgaļu izdevnīceiba.

Lindström, Liina, Pärtel Lippus \& Tuuli Tuisk 2019: The online database of the University of Tartu Archives of Estonian Dialects and Kindred Languages and the Corpus of Estonian Dialects. - Sofia Björklöf \& Santra Jantunen (eds), Multilingual Finnic. Language contact and change. Uralica Helsingiensia 14. Helsinki: Finno-Ugrian Society. 327-350. Available at: 〈https://doi.org/10.33341/uh.85040〉

Mets, Mari, Anu Haak, Triin Iva, Grethe Juhkason, Mervi Kalmus, Miina Norvik, Karl Pajusalu, Pire Teras, Tuuli Tuisk \& Lembit Vaba 2014: Eesti murded IX. Lõunaeesti keelesaarte tekstid. [Estonian dia- 
lects IX. South Estonian language island texts.] Tallinn: Eesti Keele Instituut \& Tartu Ülikool.

Niilus, Valter 1937: Valimik leivu murdetekste. Choix de textes dialectaux leivu [A selection of Leivu dialect texts]. Akadeemilise Emakeele Seltsi toimetised 31. Tartu: Akadeemilise Emakeele Seltsi kirjastus.

Ojansuu, Heikki 1912: Virolaiset siirtokunnat lättiläisalueella, niiden lähtöpaikka ja -aika [Estonian settlements in the Latvian region, their origin and time]. - Suomalainen Tiedeakademia. Esitelmät ja pöytäkirjat. 7-26.

Pajusalu, Karl 2009: Estonians of Latgale. - Valodas Austrumlatvijā: Pētījuma Dati un Rezultāti. Languages in Eastern Latvia: Data and Results of Survey. Via Latgalica, Supplement to Journal of the Humanities. Rēzekne, Latvia: Rēzeknes Augstskola. 171-181.

RAPLM/PRD (Reǵionālās attīstības un pašvaldību lietu ministrija, Pašvaldību reformu departaments [Ministry of Regional Development and Self-Government, Department of Self-Government Reform]). (2007). Administratīivi teritoriālā iedalījuma projekts [Administrative territorial division project]. [Accessed 4 April 2017.] Available at: 〈http://www.cirkulis.lv/wp-content/gallery/novadu_karte.jpg〉

Sang, August 1936: Lutsi maarahvas a. 1936 [Lutsi country folk in 1936]. Eesti Kirjandus: 399-409.

Silkāns, Ilmārs (2011, January 11): Soidi, kivki, raibakozi (pastāstīšu par Latgales igauniem) [Soidi, kivki, raibakozi. (I'll tell you about the Estonians of Latgale)]. - Ezerzeme: Aglonas, Dagdas un Krāslavas novada avize. Available at: $\langle\mathrm{http}: / / \mathrm{www}$.ezerzeme.lv/index.php?action= show\&type $=$ news \&id $=11028$ >

Šķiņķis, Pēteris 1999: Teritorijas un teritoriālās stratēgijas Latvijā [Territories and territorial strategies in Latvia. PhD Dissertation]. University of Latvia.

Turlajs, Jānis (ed.) 2012: Latvijas vēstures atlants [Historical atlas of Latvia]. Rīga: Karšu izdevniecība "Jāņa sēta".

Voolaine, Paulopriit 1925: Lutsi maarahvas 1925. a. [Lutsi country folk in 1925]. - Eesti Kirjandus: 372-379. 
Pētniecības ekspedīcijas pie Ludzas igauṇiem un valodas apguves materiālu izveide

\section{Uldis Balodis}

Ludzas igauṇi, jeb luci, ir vēsturiski dienvidigauniski runājoša kopiena, kas vismaz trīs līdz četrus gadsimtus apdzīvojusi apmēram 50 ciemus pirmskara Pildas, Nirzas, Brigu un Mērdzenes pagastos Ludzas apkaimē. No 2013. līdz 2016. gadam, kā Kone fonda stipendiāts, dokumentēju Ludzas igauṇu kopienas pašreizējos apstākḷus un uzrakstīju Ludzas igaunu valodas ābeci latviešu valodā. Raksta pirmajā daḷā aprakstu Ludzas igauņu pētniecības vēsturi, kā arī Ludzas igauņu kopienas un to pēcteču stāvokli mūsdienās. Raksta otrajā dą̧ā aprakstu Ludzas igauņu ābeci, vārdnīcu un gramatikas ievadu, kurus sastādīju savas pētniecības gaitā kā arī aprakstu ieceres to turpmākajai izmantošanai. Igauņu pētnieks Oskars Kallass (Oskar Kallas) bija pirmais, kas 19. gadsimtā plaši dokumentēja Ludzas igauņus, to kultūru un valodu. Citi pētnieki visai plaši dokumentējuši Ludzas igauņu valodu desmitgadēs pēc Kallasa pētniecības ekspedīcijas. Pēdējais Ludzas igauṇu valodas runātājs nomira 2006. gadā un pēdējais cilvēks ar plašām Ludzas igauṇu valodas zināšanām aizgāja mūǔžibā 2014. gadā. Mūsdienās daži Ludzas igauņu pēcteči vēl atceras atsevišķus vārdus un īsus teikumus Ludzas igauņu valodā, taču ikdienā šīs kopienas vairākums lieto latviešu valodu (atsevišķ̧i pēcteči arī krievu valodu) kā savu galveno sarunvalodu. 